FITRAH Jurnal Kajian Ilmu-ilmu Keislaman

Vol. 02 No. 2 Desember 2016

e-ISSN : 2460-2345, p-ISSN: 2442-6997

Web: jurnal.iain-padangsidimpuan.ac.id/index.php/F

\title{
PENGELOLAAN SUMBER DAYA INSANI DALAM MEMASARKAN PRODUK DAN JASA LEMBAGA KEUANGAN SYARIAH
}

\author{
MUHAMMAD ISA
}

Lecturer of Economy and Bisnis Islam Faculty at IAIN Padangsidimpuan

Street T. Rizal Nurdin Km. 4.5 Sihitang Padangsidimpuan 22733

Email: misastmm@gmal.com

\begin{abstract}
Now, bank and Islamic financial institutions are growing rapidly. They must show their differences from the conventional institutions one. It is the fact that most of Indonesian Moslems feel there is nothing special differences between Islamic financial institutions and conventional institutions. They conclude it from their experiences. This perception is not good for the development of Islamic financial institutions in the future. So, we must restore the policies about Islamic financial institutions management. One of them is a human resource. The employees must good in character, masteries in fiqh muamalah, Islamic financial knowledge, computers, etc. They must have commitment to practice Islamic economy in their activities.
\end{abstract}

Keywords: Human Resources, Marketing, Islamic Financial Institutions

\begin{abstract}
Abstrak
Bank dan lembaga keuangan syariah di Indonesia berkembang dengan sangat cepat. Seharusnya bank dan lembaga keuangan syariah harus memberikan pelayanan dan cita rasa yang berbeda dari lembaga keuangan konvensional. Namun kenyataannya banyak masyarakat yang merasa tidak ada perbedaan yang istimewa antara lembaga keuangan syariah dan konvensional. Hal ini disimpulkan dari pengalaman mereka selama ini. Persepsi negatif masyarakat ini akan berdampak negatif bagi pengembangan lembaga keuangan syariah ke depan. Untuk itu beberapa kebijakan dalam pengelolaan lembaga keuangan syariah perlu dibenahi. Salah satunya menyangkut aspek sumber daya insani. Seorang karyawan bank dan lembaga keuangan syariah yang diterima harus mempunyai kepribadian yang baik, menguasai ilmu figh muamalah, pengetahuan tentang lembaga keuangan syariah, komputer/IT dan sebagainya. Mereka haruslah orang-orang yang berkomitmen kuat untuk mempraktikkan ekonomi islam dalam kehidupannya.

Kata Kunci: Sumber Daya Insani, Pemasaran, Lembaga Keuangan Syariah
\end{abstract}




\section{PENDAHULUAN}

Siapapun tidak dapat menyangkal bahwa faktor manusia merupakan sentral dari setiap aktivitas maupun peristiwa di dunia ini. Majunya peradaban manusia merupakan buah karya kreativitas dan inovatifnya manusia. Menurunnya kualitas lingkungan hidup juga diakibatkan kecerobohan dan keserakahan manusia.

Dalam lingkup yang lebih sempit, misalnya pada sebuah perusahaan, manusia atau faktor sumber daya insani tetap menjadi kunci maju mundurnya perusahaan tersebut. Sebuah perusahaan manufaktur yang menerapkan teknologi canggih, menggunakan bahan baku pilihan, modal yang cukup, metode kerja terbaik, serta didukung oleh pasar yang potensial akan menjadi tak berarti apa-apa jika aspek sumber daya insani (manusia) tidak berfungsi sebagaimana mestinya. Mesin berteknologi tinggi hanya akan beroperasi baik jika dijalankan operator yang mahir dan menguasai cara kerja mesin tersebut. Modal atau dana yang berlimpah hanya akan bermanfaat secara optimal jika dikelola seorang manejer keuangan yang handal mengelola keuangan. Pasar yang potensial hanya akan bisa digarap dan dikuasai perusahaan jika manejer pemasarannya mampu merancang program-program pemasaran yang menyentuh hati dan menumbuhkan minat konsumen, di sisi lain ia harus mampu mengelola pemasaran di tengah membanjirnya produk perusahaan pesaing. Beberapa hal di atas untuk sementara telah bisa menunjukkan betapa faktor sumber daya insani (manusia) merupakan faktor yang sangat penting untuk dikelola dengan baik dalam setiap organisasi termasuk organisasi bisnis/perusahaan.

Faktor sumber daya insani atau karyawan perusahaan perlu dikelola dengan sebaik-baiknya sehingga dapat berperan optimal dan memberikan kontribusi terbaik bagi kemajuan perusahaan. Perusahaan mempelajari faktor lingkungan melalui pengamatan cermat. Artinya, perusahaan perlu mengumpulkan berbagai informasi persoalan lingkungan secara teratur dan menafsirkannya dalam kaitannya dengan bisnis perusahaan. Pengamatan merupakan tahap awal dalam memformulasi strategi dan perencanaan strategis. Sebuah pengamatan dan prakiraan dikembangkan sebagai dasar pembuatan perencanaan. Aspek penting dalam menganalisis industri adalah menentukan faktor-faktor keberhasilan usaha di pasar. Faktor-faktor tersebut antara lain berupa, produk, promosi, harga, dan tempat. Sekedar sebagai contoh, untuk 
berhasil dalam usaha makanan cepat saji, sebuah perusahaan harus memiliki lokasi yang meyakinkan, pelayanan cepat, standar kualitas produk yang taat asas, kebersihan, penyimpanan, dan harga bersaing. Perusahaan seperti Mc. Donalds, Wendy's, KFC, Burger King, dan Bakmie Gajahmada serta Indofood berhasil karena mereka memiliki karakteristik-karakteristik di atas. ${ }^{1}$

Faktor-faktor keberhasilan untuk industri lain dapat berbeda. Sebagai contoh, toko swalayan, faktor-faktor pendukung keberhasilannya dapat berupa lokasi yang strategis, produk dengan berbagai macam pilihan yang menarik, pelayanan yang baik, produk yang bermutu, kenyamanan ruangan, dan sebagainya. Jadi, hal penting adalah sebuah perusahaan harus mengetahui faktor-faktor keberhasilan kritis dari industri dan memformulasi strategi yang tepat untuk memenuhi faktor-faktor di atas. Hal demikian tidak lepas dari unsur tenaga kerja/karyawan atau Sumber Daya Insani (SDI).

Strategi SDI didasarkan pada keseluruhan strategi perusahaan dan kebutuhan taat asas. Toko swalayan, misalnya, menekankan keramah-tamahan terhadap pelanggan. Oleh sebab itu perusahaan harus menyewa, melatih dan menghargai karyawan sehingga jasa-jasa pelayanan dapat mereka sediakan dengan efektif dan efisien. ${ }^{2}$

Demikian juga halnya dengan perusahaan yang bergerak di bidang perbankan dan lembaga keuangan syariah (asuransi syariah, koperasi syariah, BMT, perusahaan pembiayaan syariah, dan lainnya) maka faktor sumber daya insani yang dimilikinya menjadi salah satu penentu kesuksesan perusahaan dalam menjalankan usahanya. Tidak dapat dipungkiri, khususnya di Indonesia, pertumbuhan lembaga keuangan syariah cukup melejit. Indikatornya antara lain banyaknya berdiri lembaga bank umum syariah, bank unit usaha syariah, asuransi syariah, bank pembiayaan rakyat syariah, maupun lembaga keuangan mikro syariah lainnya. Pertumbuhan lembaga keuangan syariah ini tentunya harus diimbangi dengan ketersediaan sumber daya insani yang handal di bidang lembaga keuangan syariah. Hal ini perlu menjadi perhatian khusus karena adanya karakteristik dan ketrampilan khusus yang perlu dimiliki setiap orang yang berkecimpung di perusahaan lembaga keuangan syariah. Seharusnya tidak semua lulusan perguruan tinggi (fresh graduate) langsung dapat dipekerjakan di perusahaan lembaga keuangan syariah karena mereka setidaknya harus

\footnotetext{
2004), hal. 23

${ }^{1}$ Syafri Mangkuprawira, Manajemen Sumber Daya Manusia Strategik (Jakarta: Ghalia Indonesia, ${ }^{2}$ Ibid.
} 
FITRAH Jurnal Kajian Ilmu-ilmu Keislaman

Vol. 02 No. 2 Desember 2016

memiliki kelebihan pengetahuan di bidang fiqh muamalat, hukum bisnis syariah, akuntansi syariah, etika bisnis islam, pemasaran syariah dan lainnya.

\section{PEMBAHASAN}

\section{Riba dan Lembaga Keuangan Syariah}

Islam merupakan ajaran yang komprehensif. Islam tidak hanya mengatur hal-hal yang bersifat ibadah namun juga hal-hal yang berkaitan dengan hubungan sesama manusia dan mahluk lainnya. Tujuannya adalah agar tugas manusia sebagai hamba Allah dan juga sebagai khalifah dapat terlaksana dengan sempurna.

Salah satu aspek yang timbul dalam hubungan sesama manusia adalah aspek perekonomian. Islam memberikan aturan-aturan yang jelas dalam hal perekonomian, salah satunya yaitu tentang pelarangan riba. Riba secara etimologis bersinonim dengan ziyadah, yang artinya tambahan. Riba jika diartikan secara linguistik artinya 'tumbuh dan membesar'. Adapun menurut istilah teknis, riba merupakan pengambilan tambahan dari harta pokok (modal) secara batil. ${ }^{3}$

Islam dengan tegas melarang praktek riba sesuai dengan ayat Alqur'an pada surah Al-Baqarah ayat 275 berikut:

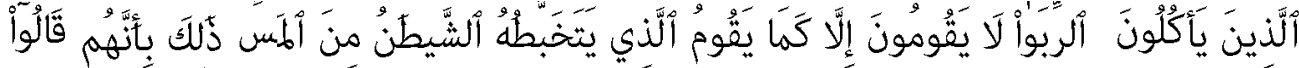

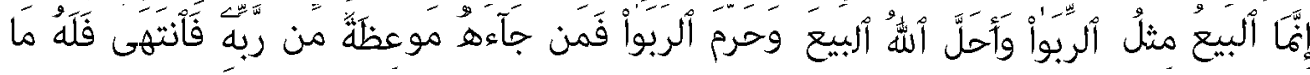

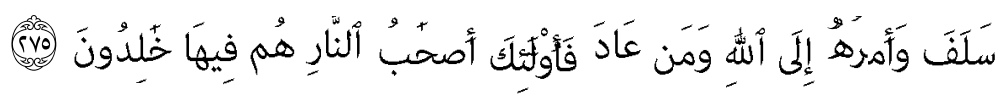

Artinya: Orang-orang yang makan (mengambil) riba tidak dapat berdiri melainkan seperti berdirinya orang yang kemasukan setan lantaran (tekanan) penyakit gila. Keadaan mereka yang demikian itu, adalah disebabkan mereka berkata (berpendapat), sesungguhnya jualbeli itu sama dengan riba, padahal Allah telah menghalalkan jual beli dan mengharamkan riba. Orang-orang yang telah sampai kepada mereka larangan dari Tuhannya, lalu terus berhenti (dari mengambil riba), maka baginya apa yang telah diambilnya dahulu (sebelum datang larangan) dan urusannya (terserah) kepada Allah. Orang yang kembali (mengambil riba), maka orang itu adalah penghuni-penghuni neraka, mereka kekal di dalamnya. ${ }^{4}$

Islam melarang riba karena akibat-akibat buruk yang ditimbulkannya. Riba, yang praktiknya saat ini dengan penggunaan sistem bunga uang, akan

\footnotetext{
${ }^{3}$ Edy Wibowo dan Untung Hendy Widodo, Mengapa Memilih Bank Syariah (Bogor:Ghalia Indonesia, 2005), hal. 55.

${ }^{4}$ Departemen Agama, Al-Qur'an dan Terjemahannya (Bandung: CV. Diponegoro, 2005), hal. 36.
} 
membuat orang tergoda untuk mengejar keuntungan dan menumpuk kekayaan sehingga uang tidak menjadi produktif dan hanya menimbulkan kesenjangan antara yang kaya dan miskin, korupsi dan pemborosan. Riba menyebabkan perasaan tidak puas dalam masyarakat dan dipergunakan oleh orang-orang kaya untuk mengeksploitasi orang miskin.

Untuk menghindari keburukan yang ditimbulkan praktik riba dikembangkanlah institusi bank dan lembaga keuangan syariah yang beroperasi tanpa bunga. Ekonomi tanpa bunga telah dilaksanakan pada permulaan Islam yang tidak sama dengan sistem kapitalis maupun komunis, namun merupakan gabungan sifat istimewa dari keduanya. Ia telah menciptakan perkembangan yang baik bagi masyarakat Islam di masa lalu, dimana tidak ada penimbunan kekayaan bagi setiap individu, tidak mengenal penyembunyian kekayaan dan tidak menarik keuntungan bagi diri sendiri. ${ }^{5}$

\section{Perkembangan Lembaga Keuangan Syariah}

Gagasan untuk mendirikan bank yang beroperasi berdasarkan prinsip Islam di dunia telah muncul sejak lama dan telah banyak digagas oleh pemikirpemikir muslim antara lain Anwar Qureshi, Naiem Siddiqi, Mahmud Ahmad, dan Mawdudi. Bank syariah modern pertama kali berdiri di Pakistan dan Malaysia pada tahun 1940. Kemudian tercatat pula dalam sejarah perbankan syariah berdirinya Mit Ghamr Lokal Saving Bank di Mesir pada tahun 1963. Bank ini pada awalnya berkembang pesat hingga dalam kurun waktu empat tahun telah membuka sembilan kantor cabang dengan nasabah sekitar satu juta orang. Tetapi karena pergolakan politik di Mesir pada tahun 1967 bank ini ditutup. Selanjutnya pada tahun 1972 di Mesir berdiri kembali bank yang beroperasi tanpa bunga yaitu Nasser Social Bank. ${ }^{6}$

Adapun ide untuk mendirikan bank yang beroperasi tanpa bunga di Indonesia secara eksplisit muncul sejak tahun 1970-an. Hal ini dibicarakan pada seminar nasional Hubungan Indonesia-Timur Tengah pada tahun 1974 dan pada tahun 1976 dalam seminar internasional yang diselenggarakan oleh Lembaga Studi Ilmu-Ilmu Kemasyarakatan (LSIK) dan Yayasan Bhinneka Tunggal Ika. Namun karena beberapa permasalahan politis dan lainnya maka ide pendirian bank syariah tersebut urung terealisasi.

\footnotetext{
${ }^{5}$ Muhammad Muslehuddin, Sistem Perbankan dalam Islam, Diterjemahkan dari "Banking and Islamic Law" oleh Aswin Simamora (Jakarta: Rineka Cipta, 1994), hal. 50.

${ }^{6}$ Heri Sudarsono, Bank dan Lembaga Keuangan Syariah: Deskripsi dan Ilustrasi (Yogyakarta:Ekonisia, 2007), hal. 28.
} 
Setelah berlangsung beberapa tahun, muncul kembali gagasan pendirian perbankan syariah di tanah air tidak padam. Gagasan ini muncul lagi sejak tahun 1988 ketika pemerintah mengeluarkan Paket Kebijakan Oktober (Pakto) yang berisi liberalisasi industri perbankan. Selanjutnya muncul lagi masalah baru di mana tak satupun Undang-undang yang mengatur bank syariah, kecuali bahwa perbankan dapat saja menetapkan bunga sebesar $0 \%$. Namun berkat dari perjuangan para ulama dan pemikir Islam akhirnya pada bulan Agustus 1990 terbentuklah kelompok kerja untuk mendirikan bank syariah di Indonesia. Rangkaian peristiwa di atas berlanjut dengan ditandatanganinya Akte Pendirian PT. Bank Muamalat Indonesia pada tanggal 1 Nopember 1991. Setelah melalui beberapa tahapan yang matang akhirnya pada tanggal 1 Mei 1992, PT. Bank Muamalat Indonesia (BMI) resmi beroperasi. ${ }^{7}$

Ketika negara-negara Asia, termasuk Indonesia, dilanda krisis moneter pada tahun 1998 banyak industri perbankan yang gulung tikar. Namun banyak pihak yang kagum kepada PT. Bank Muamalat Indonesia, yang saat itu penuh dengan keterbatasan, karena tetap mampu bertahan dan tetap dikategorikan sebagai bank yang sehat. Hal ini menjadi pemicu munculnya lembaga-lembaga perbankan syariah yang lain di samping faktor lainnya, yaitu munculnya kesadaran dan keinginan yang kuat di kalangan umat Islam untuk berbisnis dan bertransaksi secara syariah. ${ }^{8}$ Sehingga saat ini kita mengenal beberapa lembaga perbankan syariah antara lain Bank Syariah Mandiri, BNI Syariah, BRI Syariah, Bukopin Syariah, Bank Sumut Syariah, Danamon Syariah, dan sebagainya.

Berkembangnya sektor perbankan syariah di Indonesia juga tidak bisa dilepaskan dari munculnya UU No. 10 Tahun 1998 tentang perubahan UU No. 7 Tahun 1992 tentang Perbankan. Dalam undang-undang ini terdapat beberapa perubahan yang memberikan peluang yang lebih besar bagi pengembangan perbankan syariah. Munculnya undang-undang ini diikuti dengan dikeluarkannya sejumlah ketentuan pelaksanaan dalam bentuk SK Direksi BI/Peraturan Bank Indonesia, telah memberikan landasan hukum yang lebih kuat bagi pengembangan perbankan syariah di Indonesia. Peraturan-peraturan tersebut memberikan kesempatan yang luas untuk mengembangkan jaringan perbankan syariah antara lain melalui ijin pembukaan Kantor Cabang Syariah (KCS) oleh bank konvensional. Dengan kata lain, bank umum dapat menjalankan

\footnotetext{
${ }^{7}$ Ibid,. hal 30-31

${ }^{8}$ Iman Hilman, Perbankan Syariah Masa Depan (Jakarta: Senayan Abadi Publishing, 2003), hal. 3.
} 
dua kegiatan usaha, baik secara konvensional maupun berdasarkan prinsip syariah. Landasan hukum bank syariah semakin kokoh lagi setelah didukung UU No. 23 Tahun 1999 tentang Bank Indonesia, yang menyatakan bahwa Bank Indonesia dapat menerapkan kebijakan moneter berdasarkan prinsip-prinsip syariah.

Dengan lahirnya undang-undang tersebut, maka berdiri beberapa bank syariah lainnya, seperti Bank IFI membuka cabang syariah pada tanggal 28 Juni 1999, Bank Syariah Mandiri yang merupakan konversi dari Bank Susila Bakti, serta pendirian lima cabang baru syariah dari BNI. Pada bulan Februari 2000, tercatat di Bank Indonesia, bank-bank yang sudah mengajukan permohonan membuka cabang syariah, yakni Bank Niaga, Bank BTN, Bank Mega, Bank BRI, Bank Bukopin, BPD Jabar dan BPD Aceh. ${ }^{9}$

Pada perkembangan selanjutnya, disebabkan UU No. 10 Tahun 1998 dianggap belum sempurna mengakomodasi karakteristik operasional perbankan syariah yang semakin bertumbuh pesat maka lahirlah UU No. 21 Tahun 2008 tentang Perbankan Syariah. Undang-undang ini jelas merupakan jaminan bagi kepastian usaha dan jaminan perlindungan hukum yang sangat diperlukan. UU ini menjadi payung yuridis bagi semua kalangan yang berhubungan dengan bank syariah.

\section{Problematika Lembaga Keuangan Syariah}

Keberhasilan bank syariah dalam menghimpun dana masyarakat sangat berkaitan dengan kemampuan bank syariah dalam menjangkau lokasi nasabahnya. Semakin banyak jumlah kantor cabang, maka jumlah masyarakat yang menyimpan dana maupun melakukan pembiayaan di bank syariah semakin bertambah pula.

Pelayanan yang diberikan oleh bank syariah terhadap masyarakat harus terus ditingkatkan. Karena hakikat dari bisnis perbankan adalah bisnis jasa yang berdasarkan asas kepercayaan sehingga masalah kualitas layanan menjadi faktor yang sangat menentukan dalam keberhasilan usaha.

Potensi dan prospek perbankan syariah nampaknya sangat bagus untuk dikembangkan di Indonesia. Prospek yang baik ini setidaknya ditandai oleh beberapa hal. Pertama, jumlah penduduk muslim yang mayoritas di indonesia merupakan pasar potensial bagi perkembangan bank syariah. Kedua,

${ }^{9}$ Adrian Sutedi, Perbankan Syariah: Tinjauan dan Beberapa Segi Hukum (Bogor: Ghalia Indonesia, 2009), hal. 32. 
perkembangan lembaga pendidikan tinggi yang menyelenggarakan pendidikan di bidang ekonomi dan keuangan syariah yang kian pesat. Ketiga, adanya fatwa Majelis Ulama Indonesia (MUI) tentang keharaman bunga bank. Keempat, political will dari pemerintah untuk mendukung perkembangan bank syariah cukup positif dengan diterbitkannya sejumlah peraturan dan undang-undang tentang perbankan syariah. ${ }^{10}$

Pertumbuhan lembaga keuangan syariah di tanah air yang cukup menggembirakan bukannya tidak menghadapi berbagai macam permasalahan. Permasalahan yang muncul antara lain sosialisasi dan pemahaman masyarakat yang masih kurang baik tentang produk dan jasa lembaga keuangan syariah, adanya persepsi bahwa bank syariah hanya untuk kalangan muslim saja, keterbatasan jaringan kantor dan teknologi, peraturan dan perangkat hukum yang masih perlu disempurnakan, keterbatasan jumlah tenaga kerja atau sumber daya insani yang kompeten, dan segudang masalah lainnya.

Berikut ini beberapa pilar yang harus diperhatikan yang juga merupakan peluang dan tantangan dalam pengembangan perbankan syariah di Indonesia: ${ }^{11}$

1. Peningkatan pelayanan dan profesionalisme

Pada masa yang akan datang ketika bank syariah dan lembaga keuangan syariah telah dominan dan meluas ke berbagai daerah, isu halal-haram tidak bisa diandalkan lagi. Pada masa itu sebaiknya lembaga-lembaga tersebut harus mengedepankan profesionalisme dan pelayanan yang memuaskan kepada konsumen. Para praktisi bank syariah harus meyakinkan umat Islam bahwa bank syariah itu lebih baik.

2. Inovasi produk

Perkembangan teknologi informasi yang pesat saat ini telah berimbas ke berbagai sektor termasuk dunia perbankan maupun lembaga keuangan lainnya. Produk-produk perbankan dan lembaga keuangan yang ada saat ini harus dikembangkan variasi dan kombinasinya dengan dukungan teknologi informasi yang semakin canggih, sehingga mempermudah urusan dan meningkatkan efisiensi kegiatan usaha konsumen. Di sisi lain bank dan lembaga keuangan syariah harus membina kerjasama dengan lembaga-lembaga keuangan internasional, perusahaan-perusahaan bonafid untuk memperkaya variasi produknya dan perluasan jaringan

\footnotetext{
${ }^{10}$ Ibid., hal. 45.

${ }^{11}$ Ibid., hal 46-49
} 
bisnisnya. Bank dan lembaga keuangan syariah yang maju dan bertahan di masa depan adalah yang mampu menyajikan produk-produk yang kompetitif, sesuai dengan kebutuhan masyarakat, tetapi tetap sesuai dengan prinsip-prinsip syariah.

3. Sumber daya insani

Bank dan lembaga keuangan syariah harus mempersiapkan sumber daya insani (SDI) yang berkualitas dan handal, karena eksistensi kualitas sumber daya insani sangat menentukan pengembangan perbankan syariah di masa mendatang. Untuk dapat menggerakkan bisnis Islami dengan sukses, diperlukan sumber daya insani yang menguasai ilmu bisnis dan ilmu-ilmu syariah secara baik. Kenyataan yang terjadi selama ini, kebanyakan karyawan bank dan lembaga keuangan syariah merupakan alumni perguruan tinggi umum yang diberikan training singkat tentang bank dan lembaga keuangan syariah. Training seperti ini kurang memadai untuk menciptakan sumber daya insani yang benarbenar handal dan kompeten di bidang bisnis perbankan dan lembaga keuangan syariah.

4. Perluasan jaringan kantor

Tentunya dengan semakin banyak jaringan kantor yang dimiliki bank dan lembaga keuangan syariah maka akan semakin memudahkan masyarakat untuk menggunakan produk dan jasa lembaga keuangan tersebut.

5. Syariah compliance

Praktik operasional bank dan lembaga keuangan syariah harus benarbenar dijalankan berdasarkan prinsip syariah. Dengan semakin meluasnya jaringan perbankan dan lembaga keuangan syariah, maka dewan pengawas syariah harus lebih meningkatkan perannya secara aktif. Di samping itu bank dan lembaga keuangan syariah harus menjadi motor dan contoh terbaik dalam penerapan GCG (Good Corporate Governance). Insan bank dan lembaga keuangan syariah harus menjauhkan diri dari praktik-praktik bisnis yang kotor dan moral hazard. Penerapan GCG di bank dan lembaga keuangan syariah tidak saja meningkatkan kepercayaan publik kepada bank syariah, tetapi juga merupakan bagian dari upaya meningkatkan kepercayaan masyarakat kepada perbankan nasional. 
6. Edukasi yang kontinu

Upaya lain dalam memajukan bank dan lembaga keuangan syariah adalah melaksanakan edukasi masyarakat tentang sistem bank syariah, keunggulannya, prinsip-prinsip yang melandasinya, mekanisme operasional, dan sebagainya. Karena informasi keilmuan yang terbatas, masyarakat masih banyak yang menyamakan bank syariah dan bank konvensional secara mikro dan sempit. Dengan kata lain, masyarakat masih banyak yang belum mengerti betapa sistem bunga membawa dampak yang sangat mengerikan bagi keterpurukan ekonomi dunia.

\section{Peranan Sumber Daya Insani dalam Organisasi dan Kaitannya dengan Kegiatan Pemasaran.}

Seperti kita ketahui sumber daya yang dimiliki organisasi sering kita kenal dengan 6M yaitu Man (tenaga kerja atau karyawan), Money (dana atau modal), Material (Bahan baku), Methode (cara kerja atau teknologi), Machine (peralatan dan mesin-mesin), dan Market (pasar). Dari keenam sumber daya tersebut unsur tenaga kerja atau karyawan (man) merupakan yang paling penting. Alasannya karena semua unsur tersebut kecuali unsur tenaga kerja atau karyawan (man) merupakan benda mati yang tidak dapat berbuat apa-apa kecuali digerakkan dan diatur oleh manusia. Pasar yang potensial pun hanya akan bisa mendatangkan keuntungan bagi perusahaan bila digarap oleh para tenaga pemasaran yang handal, jujur, ulet, sabar, dan memahami selera pasar.

Hal yang disebutkan di atas berlaku juga pada bank dan lembaga keuangan syariah merupakan organisasi yang bersifat profit oriented. Bisnis perbankan merupakan bisnis yang jasa yang sangat tergantung kepada kepercayaan nasabah dalam bertransaksi dengan bank tersebut. Nasabah yang rasional hanya akan menyimpan uang yang dimilikinya pada lembaga bank yang diaanggapnya aman, menguntungkan, serta dilayani oleh karyawan yang ramah dan jujur. Rasa percaya nasabah kepada bank dan lembaga keuangan syariah akan tumbuh berdasarkan pengalamannya bertransaksi dengan lembaga tersebut. Jika ia mendapatkan pelayanan yang tepat waktu, pelayanan yang benar-benar sesuai syariah, pembukuan yang transparan dan jujur, sapaan yang tulus dan ramah dari karyawan, keuntungan yang sesuai, keamanan dan kenyamanan yang terjamin maka bisa dipastikan nasabah tersebut akan merasa puas. Nasabah yang merasa puas akan loyal dan melakukan pembelian ulang (repeat order) secara berkelanjutan. Dengan demikian program pemasaran produk 
dan jasa perbankan maupun lembaga keuangan syariah tersebut akan berjalan dengan sukses dan baik. Apa yang disebutkan di atas sangat berkaitan erat dengan sumber daya insani yang dimiliki perusahaan. Semua pelayanan yang diimpikan nasabah yang disebutkan di atas tadi hanya akan mampu disajikan oleh karyawan yang terpilih dan trampil. Di sinilah peran penting manejer sumber daya insani dan kaitannya dengan kegiatan pemasaran produk dan jasa perusahaan. Dapat disimpulkan bahwa kegiatan pemasaran produk dan jasa perusahaan akan sukses jika ditopang penuh, tepat, terintegrasi, dinamis, dan sinergis dengan pengelolaan sumber daya insani perusahaan.

\section{Fungsi Manajemen Sumber Daya Insani Organisasi (Perspektif Islam)}

Fungsi manajemen sumber daya manusia, dalam khazanah ilmu Ekonomi Islam dikenal dengan manajemen sumber daya insani, meliputi perencanaan, pengorganisasian, pengarahan, pengendalian, pengadaan, pengembangan, kompensasi, pengintegrasian, pemeliharaan, kedisiplinan, dan pemberhentian. ${ }^{12}$

\section{Perencanaan}

Perencanaan (human resources planning) adalah merencanakan tenaga kerja secara efektif dan efisien agar sesuai dengan kebutuhan perusahaan dalam mencapai tujuan perusahaan. Perencanaan dilakukan dengan menetapkan program kepegawaian. Program kepegawaian meliputi pengorganisasian, pengarahan, pengendalian, pengadaan, pengembangan, kompensasi, pengintegrasian, pemeliharaan, kedisiplinan, dan pemberhentian karyawan. Program kepegawaian yang baik akan membantu tercapainya tujuan perusahaan, karyawan dan masyarakat.

Suatu perencanaan selalu berkaitan dengan tujuan masa depan. Mengingat masa depan itu senantiasa berubah dan tidak menentu, maka suatu perencanaan harus benar-benar cermat dan matang. Perencanaan sumber daya insani atau tenaga kerja harus senantiasa berpijak pada kenyataan yang ada, disertai dengan asumsi-asumsi untuk masa depan. Perencanaan tenaga kerja mengandung implikasi dan hal pokok sebagai berikut: ${ }^{13}$

a. Mengumpulkan informasi secara reguler.

${ }^{12}$ Malayu S.P. Hasibuan, Manajemen Sumber Daya Manusia (Jakarta: Bumi Aksara, 2011), hal.

${ }^{13}$ Susilo Martoyo, Manajemen Sumber Daya Manusia (Yogyakarta: BPFE, 2000),hal. 20 
b. Menganalisa permintaan dan penawaran tenaga kerja masa kini dan masa datang, serta mencari ketidakseimbangan yang timbul.

c. Menggunakan hasil analisa untuk bahan penyusun kebijaksanaan, program/proyek dan kegiatan di bidang ketenagakerjaan dan kesempatan kerja.

d. Menyangkut pengembangan dan pemanfaatan sumber daya manusia di tingkat nasional, sektoral, wilayah dan menurut jenis jabatan.

e. Melaksanakan monitoring secara terus menerus terhadap kebijaksanaan yang telah dilaksanakan dan yang penting segera melaksanakan perubahan/penyesuaian apabila diperlukan.

f. Mengintegrasikan perencanaan tenaga kerja ke dalam perencanaan dan pelaksanaan pembangunan sosial ekonomi dan menjaga agar kedua hal tersebut saling menunjang.

Secara singkat pada instansi bank dan lembaga keuangan syariah perlu ditetapkan kualitas/mutu tenaga kerja yang diinginkan dan persyaratan yang harus diperlukan, misalnya bisa berbahasa Arab minimal pasif, memiliki nilai mata kuliah fiqh muamalat minimal $B$, bersedia menggunakan busana muslim, dan sebagainya. Perlu juga dihitung jumlah ideal tenaga kerja yang dibutuhkan oleh lembaga tersebut.

\section{Pengorganisasian}

Pengorganisasian adalah kegiatan untuk mengorganisasi semua karyawan dengan menetapkan pembagian kerja, hubungan kerja, delegasi wewenang, integrasi, dan koordinasi dalam bagan organisasi. Organisasi hanya alat untuk mencapai tujuan. Dengan melaksanakan pengorganisasian yang baik akan membantu terwujudnya tujuan secara efektif. ${ }^{14}$

Islam mengajarkan agar dalam pengorganisasian, termasuk dalam pembagian pekerjaan, harus diserahkan kepada ahlinya berdasarkan pertimbangan kompetensi. Hal ini sesuai dengan firman Allah SWT. dalam Alqur'an surah Yusuf: 55 dan Al-Qashash:26 berikut:

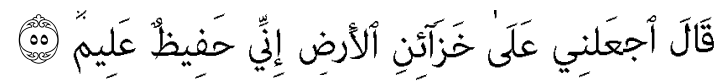

\footnotetext{
${ }^{14}$ Malayu S.P. Hasibuan, Op. Cit., hal. 22.
} 
Artinya: Dia (Yusuf) berkata, "Jadikanlah aku bendaharawan negeri (Mesir), karena sesungguhnya aku adalah orang yang pandai menjaga, dan berpengetahuan. ${ }^{15}$

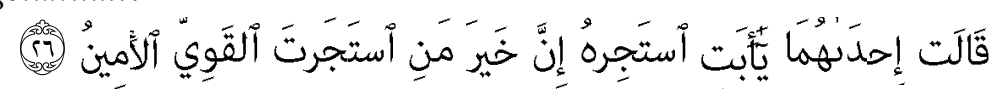

Artinya: Berkata salah seorang anaknya: Hai ayahku, ambillah dia (Musa) sebagai pekerja (menggembalakan ternak), karena sebaik-baiknya pekerja ialah yang kuat lagi jujur. ${ }^{16}$

Berdasarkan ayat di atas maka karyawan bank dan lembaga keuangan syariah harus diangkat berdasarkan kompetensi yang dimilikinya. Apa yang terjadi pada saat ini dimana banyak terjadi keluhan masyarakat yang mengatakan bertransaksi di bank syariah tidak ada bedanya dengan bank konvensional mungkin salah satunya disebabkan kesalahan dalam rekrutmen karyawan selama ini. Banyak karyawan bank syariah yang sebenarnya tidak memiliki latar belakang pendidikan ekonomi syariah. Mereka sebenarnya tidak termotivasi menjadi penggiat ekonomi syariah tetapi hanya karena motif salary/gaji semata. Mereka tidak memiliki pengetahuan yang utuh tentang ekonomi dan bisnis syariah tetapi hanya bermodalkan kursus singkat saja seputar ekonomi dan bisnis syariah. Akibatnya masyarakat tidak merasakan sentuhan ekonomi dan bisnis syariah yang sebenarnya walaupun bertransaksi di lembaga yang notabene berbasis syariah. Untuk ke depan, hal semacam ini harus diperbaiki dan disesuaikan dengan aturan yang benar.

\section{Pengarahan}

Pengarahan (directing) adalah kegiatan mengarahkan semua karyawan, agar mau bekerja sama dan bekerja efektif serta efisien dalam membantu tercapainya tujuan perusahaan, karyawan, dan masyarakat. Pengarahan dilakukan pemimpin dengan menugaskan bawahan agar mengerjakan semua tugasnya dengan baik. Islam mengajarkan seorang pemimpin harus mengayomi bawahannya dan mendengarkan aspirasi mereka dalam pengambilan keputusan. Sehingga para bawahan merasa diperhatikan dan menimbulkan rasa tanggung jawab dalam

\footnotetext{
${ }^{15}$ Departemen Agama, Al-Qur'an dan ....... hal. 193.

${ }^{16}$ Ibid., hal. 310.
} 
menuntaskan pekerjaannya dengan baik. Hal ini sesuai dengan ayat Alqur'an surah Ali Imran ayat 159 berikut:

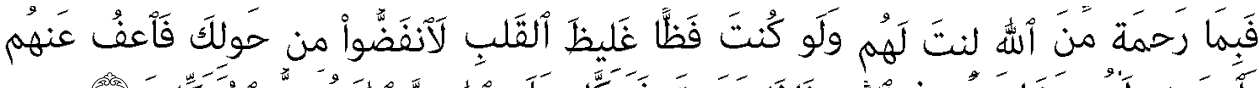

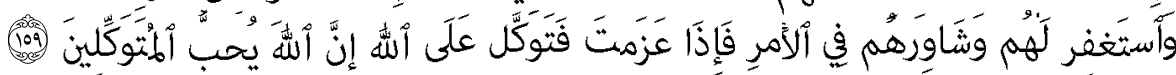

Artinya: Maka berkat rahmat Allah engkau (Muhammad) berlaku lemah lembut terhadap mereka. Sekiranya engkau bersikap keras dan berhati kasar, tentulah mereka menjauhkan diri dari sekitarmu. Karena itu maafkanlah mereka dan mohonkanlah ampunan untuk mereka, dan bermusyawarahlah dengan mereka dalam urusan itu. Kemudian, apabila engkau telah membulatkan tekad, maka bertawakkallah kepada Allah. Sungguh, Allah mencintai orang yang bertawakkal. ${ }^{17}$

\section{Pengendalian}

Pengendalian (controlling) adalah kegiatan mengendalikan semua karyawan agar mentaati peraturan-peraturan perusahaan dan bekerja sesuai dengan rencana. Apabila terdapat penyimpangan atau kesalahan, diadakan tindakan perbaikan dan penyempurnaan rencana. Pengendalian karyawan meliputi kehadiran, kedisiplinan, perilaku, kerjasama, pelaksanaan pekerjaan, dan menjaga situasi lingkungan pekerjaan. Dalam dunia bank dan lembaga keuangan syariah kegiatan pengendalian ini perlu menjadi perhatian khusus mengingat sedikit saja terjadi penyimpangan dan kecurangan (fraud) dalam pengelolaan bisnisnya akan berdampak langsung kepada ketidakpercayaan nasabah untuk menggunakan produk dan jasa bank dan lembaga keuangan syariah tersebut.

\section{Pengadaan}

Pengadaan (procurement) adalah proses penarikan calon karyawan, seleksi calon karyawan, penempatan, orientasi, dan induksi dalam rangka mendapatkan karyawan yang sesuai dengan kebutuhan perusahaan. Kegiatan pengadaan yang sesuai aturan akan menjamin tercapainya tujuan organisasi atau perusahaan. Indonesia punya masa lalu yang kelam khususnya dalam kegiatan pengadaan karyawan baik pada instansi pemerintah maupun swasta. Bahkan hal tersebut diduga masih terjadi sampai sekarang walaupun intensitasnya makin berkurang. Akibatnya Indonesia terpuruk dalam berbagai bidang dibandingkan

\footnotetext{
${ }^{17}$ Ibid., hal 56.
} 
negara lain. Hal itu disebabkan kualitas pekerjaan karyawan yang rendah dan tidak bertanggung jawab dengan pekerjaannya. Karyawan yang diangkat tidak berdasarkan kompetensi, tetapi berdasarkan korupsi, kolusi dan nepotisme (KKN) tentunya hanya akan mendatangkan malapetaka di kemudian hari pada suatu organisasi. Islam sangat melarang hal tersebut dan sebaliknya mendorong agar pemberian pangkat maupun jabatan didasarkan atas kecakapan yang dimiliki seseorang. Bisnis perbankan dan lembaga keuangan syariah termasuk kategori industri jasa. Dalam industri jasa boleh dikatakan kualitas pelayanan kepada nasabah merupakan hal vital dalam menjamin kelangsungan hidup perusahaan tersebut di masa depan.

\section{Pengembangan}

Pengembangan (development) adalah proses peningkatan ketrampilan teknis, teoretis, konseptual, dan moral karyawan melalui pendidikan dan pelatihan. Pendidikan dan pelatihan yang diberikan harus sesuai dengan kebutuhan pekerjaan masa kini maupun masa depan. Kita menyadari kebudayaan manusia sangat dinamis, teknologi yang selalu mengalami perkembangan dan penyempurnaan. Hal itu semua menuntut agar para karyawan bank syariah dan lembaga keuangan syariah selalu meningkatkan ilmu yang dimilikinya sehingga dapat mengikuti perkembangan teknologi dan juga perubahan selera nasabah. Hal ini sesuai dengan ayat Alqur'an surah An-Nahl:43 berikut:

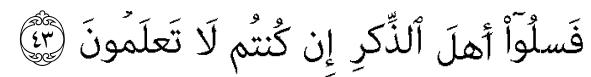
Artinya: Oleh karena itu, bertanyalah kalian kepada ahli dzikir (ilmu) jika kalian tidak mengetahuinya. ${ }^{18}$

Dari ayat tersebut di atas terkandung adanya prinsip bahwa setiap orang hendaklah selalu menambah pengetahuannya sehingga kebodohan dirinya dapat dikurangi atau dihilangkan. Apabila seseorang ingin dapat mengerjakan pekerjaan dengan lebih baik atau lebih sempurna dari sebelumnya, maka ia harus terus menerus menambah pengetahuan di bidangnya. Prinsip yang digariskan oleh Islam agar seseorang senantiasa bertanya kepada ahlinya jika ia tidak mengetahui atau dengan kata lain tuntutan untuk terus menerus menuntut ilmu,

${ }^{18}$ Ibid., hal. 217 
merupakan hal yang harus dilakukan oleh setiap muslim untuk dapat melaksanakan pekerjaannya dengan baik. Karena bekerja dengan baik adalah salah satu bagian dari asas kerja Islami. ${ }^{19}$ Dalam lembaga bank dan keuangan syariah hal ini dapat diwujudkan antara lain dengan mengikutkan karyawan dalam kursus dan pelatihan, seminar maupun sosialisasi peraturan dan kebijakan terbaru.

\section{Kompensasi}

Kompensasi adalah pemberian balas jasa langsung dan tidak langsung, uang atau barang kepada karyawan sebagai imbalan jasa yang diberikan kepada perusahaan. Prinsip kompensasi adalah adil dan layak. Adil diartikan sesuai dengan prestasi kerjanya, layak diartikan dapat memenuhi kebutuhan primernya serta berpedoman pada batas upah minimum pemerintah. Dalam ajaran Islam dianjurkan untuk menyegerakan pembayaran upah. Pembayaran upah yang adil, layak serta tepat waktu akan mendorong semangat kerja dan kepuasan kerja karyawan. Hal ini harus menjadi perhatian serius pihak manajemen perusahaan. Islam mengajarkan tiga asas pemberian kompensasi yaitu: keadilan, timbal balik, dan kesepakatan. Asas keadilan artinya pekerja berhak mendapat upah atau gaji setelah lelah bekerja dalam waktu yang ditentukan melalui perjanjian yang disetujui majikan dan pekerja. Timbal balik artinya dilarang memberi upah di bawah tarif yang sewajarnya tanpa persetujuan pekerja. Sebaliknya, pekerja tidak boleh memaksa majikan untuk menaikkan upah atau gaji jika kerja yang dilakukan tidak setimpal. Asas kesepakatan artinya penetapan besarnya gaji dan aturan lainnya bergantung kepada hasil kesepakatan antara majikan dan pekerja. ${ }^{20}$

\section{Pengintegrasian}

Pengintegrasian adalah kegiatan untuk mempersatukan kepentingan perusahaan dan kebutuhan karyawan, agar tercipta kerjasama yang serasi dan saling menguntungkan. Perusahaan memperoleh laba sedangkan si karyawan mendapatkan penghasilan untuk memenuhi kebutuhannya. Pendekatan pengintegrasian didasarkan atas anggapan

\footnotetext{
${ }^{19}$ Muhammad Thalib, 40 Pedoman Membina Etos \& Semangat kerja Islami(Yogyakarta: Ma'alimul Usrah, 2008), hal.53-54

${ }^{20}$ Muhammad Sulaiman \& Aizuddinur Zakaria, Jejak Bisnis Rasul (Jakarta: Penerbit Hikmah, 2010), hal. 309-310
} 
bahwa karyawan adalah kekayaan utama perusahaan yang perlu dipelihara secara manusiawi, bukan diperlakukan seperti faktor produksi pasif lainnya yang dapat dimanfaatkan sekehendak hati. Bila karyawan merasa dihargai sebagai manusia maka akan meningkatkan kepuasan kerjanya selanjutnya akan menimbulkan semangat dan gairah dalam bekerja. Dalam operasional bank dan lembaga keuangan syariah diharapkan sikap positif karyawan dalam melayani nasabah akan menimbulkan loyalitas nasabah.

\section{Pemeliharaan}

Pemeliharaan (maintenance) adalah kegiatan untuk memelihara atau meningkatkan kondisi fisik, mental, dan loyalitas karyawan, agar mereka tetap mau bekerja sama sampai pensiun. Pemeliharaan yang baik dilakukan dengan program kesejahteraan yang berdasarkan kebutuhan sebagian besar karyawan. Hal ini juga cukup penting untuk diperhatikan pihak manajemen sehingga karyawan dapat bekerja dengan tenang dan berkontribusi optimal bagi kemajuan perusahaan.

10. Kedisiplinan

Kedisiplinan merupakan salah satu kunci terwujudnya tujuan karena tanpa disiplin yang baik sulit terwujud tujuan yang maksimal. Kedisiplinan adalah keinginan dan kesadaran untuk mentaati peraturanperaturan perusahaan dan norma-norma sosial. Islam sangat menganjurkan penegakan disiplin dalam berbagai lapangan kehidupan manusia. Dalam sejarah Islam kita mengetahui bahwa Nabi Muhammad SAW selalu berusaha menegakkan disiplin tentaranya. Misalnya sebelum berperang di Uhud, Rasulullah meluruskan barisan tentara Islam dengan berjalan kaki dan mempersiapkan dan mempersiapkan para sahabat untuk berperang, kemudian berkata: Majulah wahai fulan dan mundurlah wahai fulan (untuk meluruskan barisan). ${ }^{21}$

Dalam pengelolaan bank dan lembaga keuangan syariah, kedisiplinan karyawan perlu ditegakkan demi mendukung terciptanya pelayanan syariah kepada nasabah dengan memuaskan. Jangan sampai timbul kesan di masyarakat bahwa sebagian besar bank dan lembaga keuangan syariah memiliki pelayanan tidak lebih baik dari bank konvensional bahkan lebih buruk dari bank konvensional.

${ }^{21}$ Ibid., hal. 314 
FITRAH Jurnal Kajian Ilmu-ilmu Keislaman

Vol. 02 No. 2 Desember 2016

\section{Pemberhentian atau Pemensiunan}

Pemberhentian adalah putusnya hubungan kerja seseorang dari suatu perusahaan. Pemberhentian ini bisa jadi disebabkan oleh keinginan karyawan, keinginan perusahaan, kontrak kerja berakhir, pensiun, dan sebab-sebab lainnya. Pemberhentian karyawan haruslah dilakukan dengan adil, rasional, sesuai aturan dan manusiawi. Memberhentikan karyawan dengan hormat maupun tidak hormat bukanlah berarti memutuskan silaturahmi perusahaan dengan karyawan. Sebaiknya perusahaan juga harus berupaya agar pensiunan karyawannya masih bisa menjalani hidup secara wajar dan bahagia walaupun tidak bekerja lagi pada perusahaan. Sebuah bank atau lembaga keuangan syariah sebaiknya memberikan semacam program persiapan pensiun kepada calon karyawan yang akan pensiun misalnya berupa pelatihan wirausaha, kesehatan, pembinaan mental/psikologis dan sebagainya. Hal ini dilakukan dengan harapan para pensiunan karyawan tersebut dapat hidup normal, wajar, terhormat, dan bahagia dalam menjalani masa pensiunnya. Sedangkan pemberhentian karyawan dengan tidak hormat sebaiknya dilakukan dengan pertimbangan matang, rasional, transparansi, bertanggung jawab, dan manusiawi. Perusahaan harus menciptakan suatu kondisi dimana karyawan yang akan diberhentikan tersebut memahami alasan pemberhentiannya dan ikhlas menerimanya bahkan ia merasa hal tersebut sebagai pembelajaran berharga baginya untuk menapaki masa depannya nanti.

\section{PENUTUP}

Perkembangan bank dan lembaga keuangan syariah yang semakin pesat dewasa ini merupakan sesuatu yang patut disyukuri. Dengan perkembangan bank dan lembaga keuangan syariah yang semakin pesat ini diharapkan kegiatan perekonomian umat akan semakin maju dan mampu menunjukkan bahwa Islam bukan hanya sekedar ajaran yang berupa konsep saja tetapi bisa diaktualisasikan dalam berbagai aspek kehidupan. Islam mampu membuktikan kebenarannya sebagai rahmatan lil alamin.

Di sisi lain, perkembangan bank dan lembaga keuangan syariah ini perlu dibarengi dengan penyediaan sumber daya insani yang kompenten, handal, dan profesional dalam bidang ekonomi dan bisnis syariah. Masyarakat benar-benar 
menantikan pelayanan bank dan lembaga keuangan syariah yang menentramkan dan menguntungkan. Salah satu kuncinya adalah pada aspek sumber daya insani/karyawan yang dimiliki perusahaan. Paradigma pengelolaan sumber daya insani di bank dan lembaga keuangan syariah saat ini perlu disempurnakan dan ditata ulang agar tercipta suatu lembaga keuangan syariah yang ideal. Rekrutmen karyawan bank dan lembaga keuangan syariah harus benar-benar mengutamakan kompetensi, bebas dari kecurangan, serta terencana dengan baik. Proses pengembangan karyawan harus secara dilakukan secara berkesinambungan dan menunjukkan distingsi kesyariahan. Pemberian kompensasi harus diberikan secara adil, layak, dan tepat waktu agar dapat meningkatkan moral kerja dan semangat kerja karyawan. Pembinaan semangat kerja dan memotivasi karyawan harus tetap dilaksanakan dalam suasana kekeluargaan dan sesuai dengan nilai-nilai Islam sehingga terbentuk suatu lembaga yang benar-benar sesuai syariah. Bank dan lembaga keuangan syariah harus benar-benar menjadi teladan dalam memanusiakan pekerjanya. Setiap karyawan merupakan bagian dari keluarga besar perusahaan yang perlu diperhatikan bukan hanya ketika ia aktif menjadi karyawan perusahaan tetapi bahkan setelah pensiun ia masih merasa menjadi bagian penting dari perusahaan.

Jika hal-hal di atas dapat dilaksanakan dalam pengelolaan sumber daya insani/karyawan bank dan lembaga keuangan syariah maka diharapkan bank dan lembaga keuangan syariah akan lebih maju di masa depan dan dapat memainkan peranan penting dalam mensejahterakan umat manusia. Keluhan masyarakat yang menyatakan bahwa bank dan lembaga keuangan syariah sama saja dengan bank konvensional sedikit demi sedikit akan terkikis habis. 


\section{DAFTAR PUSTAKA}

Adrian Sutedi, Perbankan Syariah: Tinjauan dan Beberapa Segi Hukum, Bogor: Ghalia Indonesia, 2009.

Departemen Agama, Al-Qur'an dan Terjemahannya, Bandung: CV. Diponegoro,2005.

Edy Wibowo dan Untung Hendy Widodo, Mengapa Memilih Bank Syariah, Bogor:Ghalia Indonesia, 2005.

Hasibuan, Malayu S.P., Manajemen Sumber Daya Manusia, Jakarta: Bumi Aksara, 2011.

Heri Sudarsono, Bank dan Lembaga Keuangan Syariah: Deskripsi dan Ilustrasi, Yogyakarta:Ekonisia, 2007.

Iman Hilman, Perbankan Syariah Masa Depan, Jakarta: Senayan Abadi Publishing, 2003.

Muhammad Muslehuddin, Sistem Perbankan dalam Islam, Diterjemahkan dari "Banking and Islamic Law" oleh Aswin Simamora, Jakarta: Rineka Cipta, 1994.

Muhammad Sulaiman \& Aizuddinur Zakaria, Jejak Bisnis Rasul, Jakarta: Penerbit Hikmah, 2010.

Muhammad Thalib, 40 Pedoman Membina Etos \& Semangat kerja Islami, Yogyakarta: Ma'alimul Usrah, 2008.

Susilo Martoyo, Manajemen Sumber Daya Manusia, Yogyakarta: BPFE, 2000.

Syafri Mangkuprawira, Manajemen Sumber Daya Manusia Strategik, Jakarta: Ghalia Indonesia, 2004. 